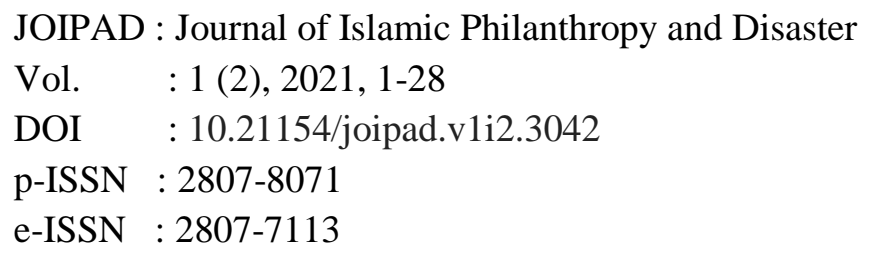

\title{
Analisis Pendistribusian ZIS dalam Meningkatkan Kesejahteraan Mustahik di Yayasan Indonesia Mulia Bekasi
}

\section{Silmi Kapah Anisa ${ }^{1}$, Ade Nur Rohim ${ }^{2}$, and Sahlan Hasbi ${ }^{3}$}

1,2 Universitas Pembangunan Nasional Veteran Jakarta, Indonesia, silmi.kapah@upnvj.ac.id, adenurrohim@upnvj.ac.id

${ }^{3}$ Universitas Djuanda Bogor, Indonesia, sahlan.hasbi@unida.ac.id

\begin{abstract}
Islam requires its people to be able to set aside some of their assets to those who are entitled, including zakat, infaq and alms (ZIS). In addition, the distribution of zakat serves to help the poor in fulfilling their daily needs. Therefore, the more muzakki who pay zakat, the welfare of mustahik will increase optimally. Welfare is based on the concept of maqasid sharia which includes all aspects related to the afterlife, namely religion, soul, mind, lineage and property. This study aims to analyse the distribution mechanism of ZIS funds at Yayasan Indonesia Mulia Bekasi and the implications of the distribution on the welfare of mustahik. This research used descriptive qualitative method with primary and secondary data approach. Primary data was obtained directly through interviews. While secondary data was obtained through observation and documentation. The results of this study indicate that the distribution of ZIS funds at the Indonesia Mulia Bekasi foundation has been effective and on target so that the funds
\end{abstract}


can be allocated according to the needs of each program. In addition, the distribution of zakat funds has a significant impact in improving the welfare of mustahik, especially orphans and poor people.

Keywords: Distribution, Welfare, ZIS Funds

\begin{abstract}
Abstrak
Islam mewajibkan umatnya untuk dapat menyisihkan sebagian harta yang dimiliki kepada orang yang berhak diantaranya zakat, infak dan sedekah (ZIS). Selain itu, penyaluran zakat berfungsi untuk membantu kaum dhuafa dalam memenuhi kebutuhan hidup. Maka dari itu semakin banyak muzaki yang membayar zakat maka kesejahteraan mustahik akan mengalami peningkatan secara optimal. Kesejahteraan berdasarkan konsep maqasid syariah yang mencakup segala aspek berkaitan dengan dunia akhirat yaitu agama, jiwa, akal, keturunan dan harta. Penelitian ini bertujuan untuk menganalisis mekanisme pendistribusian dana ZIS pada Yayasan Indonesia Mulia Bekasi dan implikasi pendistribusian terhadap kesejahteraan mustahik. Penelitian ini menggunakan metode kualitatif deskriptif dengan pendekatan data primer dan sekunder. Data primer yaitu data yang diperoleh secara langsung melalui wawancara. Sedangkan data sekunder yaitu data yang diperoleh melalui observasi dan dokumentasi. Hasil penelitian ini menunjukkan bahwa penyaluran dana ZIS di Yayasan Indonesia Mulia Bekasi sudah efektif dan tepat sasaran sehingga dana tersebut dapat dialokasikan sesuai dengan kebutuhan program masing-masing. Selain itu, penyaluran dana zakat memiliki dampak yang signifikan dalam meningkatkan kesejahteraan mustahik khususnya anak yatim dan dhuafa.
\end{abstract}

Kata kunci: Dana ZIS, Kesejahteraan, Pendistribusian 


\section{PENDAHULUAN}

Indonesia merupakan penduduk muslim terbesar di seluruh dunia (Syahadah, 2017). Sehingga Negara Indonesia mempunyai potensi zakat yang sangat besar. Menurut puskas baznas, potensi zakat di Indonesia mencapai 233,8 triliun, sedangkan penghimpunan ZIS secara nasional pada tahun 2019 melalui OPZ resmi mencapai 10 triliun atau masih 5,2 persen dari potensi zakat (Baznas, 2020).

Maka dari itu amil mempunyai peran penting dalam mengelola zakat, untuk dapat memaksimalkan perekonomian umat Islam. Jika tidak ada amil, yang profesional maka, sangat sulit zakat itu bisa optimal. apabila pengelolaan zakat yang dilakukan tidak transparan akan mengakibatkan kurangnya kepercayaan muzaki dalam menyalurkan dananya. Pengelolaan zakat yang tidak berkompeten atau tidak profesional akan mempengaruhi kinerja pengelola zakat. Sehingga muzaki lebih nyaman mendistribusikan zakat secara individu (Ansori, 2018).

Allah swt menganjurkan bagi umat muslim untuk mengeluarkan zakat dan juga dana sukarela berupa infak dan sedekah. Penerima infak dan sedekah jauh lebih luas daripada zakat, karena penyaluran infak maupun sedekah bisa disalurkan kepada siapapun yang membutuhkan. Oleh karena itu infak memiliki manfaat bagi kehidupan, selain dapat berbagi kebaikan kepada orang yang menerima, kebaikan juga akan berbalik pada diri sendiri dan pemberi infak tidak akan pernah rugi, karena hanya mengharapkan ridha Allah swt (Wahyuningsih, 2018).. Sedangkan penerima zakat dikategorikan untuk delapan ashnaf yaitu fakir, miskin, amil, mu'allaf, riqab, gharim, fisabilillah dan ibnu sabil.

Penyaluran dana zakat di Indonesia terbagi menjadi dua jenis yaitu distribusi konsumtif dan distribusi produktif. Distribusi konsumtif merupakan zakat yang dilakukan secara langsung untuk mereka yang lebih membutuhkan khususnya fakir miskin. Penyaluran zakat yang digunakan dalam memenuhi kebutuhan pokok antara lain sandang, pangan dan papan. Sebaliknya pendistribusian zakat produktif ialah dana zakat yang dapat dialokasikan pada mustahik secara produktif dan zakat dimanfaatkan dengan diberikan modal untuk meningkatkan usaha sehingga dapat memenuhi kebutuhan (Marbun, 2019).

Pendistribusian dana zakat merupakan suatu kegiatan yang berkaitan dengan kurangnya financial seseorang (Marbun, 2019) Pendistribusian dana zakat oleh mustahik haruslah sesuai dengan 
ajaran Islam dengan memperhatikan asas keadilan, kewilayahan dan pemerataan. Dikarenakan zakat bukan hanya melalui konsumtif saja, melainkan dapat mengembangkan melalui produktif sehingga mampu mencapai pemerataan zakat (Afni, 2020).

Sehingga pendistribusian zakat memiliki pengaruh yang besar karena tiap lembaga tidak lepas dari permasalahan distribusi ataupun masyarakat yang menerima dana zakat. Selain itu lembaga pengelola zakat juga berhak untuk memilih kebijaksanaan saluran distribusi. Hal tersebut tentunya pendistribusian dana ZIS memiliki sistem yang harus dikendalikan dengan baik, melalui pengumpulan, pendistribusian dan pendayagunaan. Dengan begitu penerapannya bisa berjalan dengan baik dan memenuhi ekspektasi (Solihati, 2017).

Dalam Islam, salah satu amalan yang paling mulia ialah memelihara anak yatim, karena anak yatim lebih membutuhkan perhatian dibandingkan anak yang masih memiliki kedua orang tua. Oleh karena itu Islam sangat memperhatikan keadaan anak yatim dengan berbuat baik kepada mereka, mengurus dan merawat mereka hingga dewasa (Kamalia et al., 2018).

Yatim berasal dari bahasa arab artinya anak yang telah ditinggalkan ayahnya karena meninggal dunia dan belum baligh, baik kaya atau miskin, laki-laki ataupun perempuan. Sehingga Islam menempatkan anak yatim dalam posisi yang sangat istimewa, dalam Al-Qur'an tercatat sebanyak 22 ayat tentang anak yatim diantarnya: surah al-an'am ayat 152, ad-dhuha ayat 6 dan 9, al-isra ayat 34, al-fajr ayat 17 , al-maun ayat 2 , al-insan ayat 8 , al-balad ayat 15 , al-kahfi ayat 82, al-baqarah ayat 83, 177, 215 dan 220, an-nisa ayat 2, 3, 6, 8, 10, 36 dan 127, al-anfal ayat 41 dan al-hasyr ayat 7 . Selain anak yatim piatu yang menerima zakat, ada pula fakir miskin yang berhak menerima zakat karena ketidakmampuan untuk memenuhi kehidupan sehari-hari (Riskyana, 2019).

Dengan ini, dalam perspektif Islam memiliki unsur kesejahteraan yang disebut maqasid syariah antara lain ad-diin, annafs, aql, nasl dan mal. Ad-diin atau melindungi agama dari segi pemahamannya yang dilakukan para mustahik. An-nafs atau perlindungan terhadap jiwa melalui kesehatan mustahik. Aql atau perlindungan terhadap akal melalui pengetahuan wawasan mustahik. Nasl atau perlindungan terhadap keturunan yaitu perlindungan keluarga. Mal atau perlindungan terhadap harta melalui pendapat yang dimiliki mustahik (Robimadin, 2020). 
Berdasarkan penelitian terdahulu bahwa penulis menilai belum adanya penelitian yang membahas mengenai pendistribusian ZIS dalam meningkatkan kesejahteraan mustahik di Yayasan Indonesia Mulia Bekasi. Oleh karena itu penelitian ini dilakukan untuk mengetahui mekanisme pendistribusian dana ZIS di Yayasan Indonesi Mulia dan implikasi pendistribusian terhadap kesejahteraan mustahik. Maka dari itu, penelitian ini memfokuskan untuk mengkaji distribusi zakat konsumtif melalui program pendistribusian ZIS pada Yayasan terhadap kesejahteraan mustahik.

Penelitian ini bertujuan untuk melihat sejauh mana keberhasilan program pendistribusian dana ZIS konsumtif dalam meningkatkan kesejahteraan mustahik. Kemudian setelah mengetahui hal tersebut, mampu mempertimbangkan dan mengambil keputusan yang dapat menentukan tingkat efektivitasnya.

\section{TINJAUAN LITERATUR}

\section{Zakat}

Secara bahasa, zakat berasal dari bahasa arab artinya suci, bertambah dan berkah (Nur, 2018). Qaradhawi dalam bukunya fiqh ekonomi syariah yang telah diterjemahkan oleh Mardani (2012) berjudul fiqh muamalah bahwa istilah zakat merupakan harta yang wajib diberikan kepada orang yang berhak (Mardani, 2012). Maka dari itu, zakat memiliki peran penting yang dapat meningkatkan perekonomian umat Islam dan instrumen ini mampu mensejahterakan masyarakat (Nurhasanah \& Suryani, 2018).

Qaradhawi dalam bukunya zakat yaitu perekonomian modern diterjemahkan oleh Hafidhuddun (2002) bahwa awal mula harta itu berupa emas dan perak (Hafidhuddin, 2002). Zakat terbagi menjadi dua jenis yaitu zakat maal dan zakat fitrah. Zakat maal merupakan bagian awal kekayaan seseorang yang mewajibkan untuk berbagi, khususnya orang tertentu yang sudah mencapai nilai minimum dan dimiliki untuk batas waktu tertentu. Syarat kekayaan untuk dizakati yakni; kepemilikan sepenuhnya, cukup nisab, tidak ada hutang kecuali kebutuhan dasar, satu tahun telah berlalu. Zakat fitrah merupakan zakat yang harus dikeluarkan bagi setiap muslim di bulan ramadhan. Manfaat zakat bagi muzaki ialah dapat melaksanakan salah satu rukun Islam. Oleh karena itu, dengan menjalankan kewajiban zakat, bisa mencapai tujuan maqasid syariah yaitu melestarikan agama selain itu zakat berfungsi untuk menyucikan harta, sehingga 
lembaga zakat telah membantu muzaki untuk mencapai dua tujuan syariah yakni menjaga agama dan pemeliharaan kekayaan, lembaga zakat harus membantu muzaki membayar zakat dengan tepat dan benar (Hudayati \& Tohirin, 2019). Berdasarkan firman Allah swt dalam Quran Surat At-Taubah ayat 60.

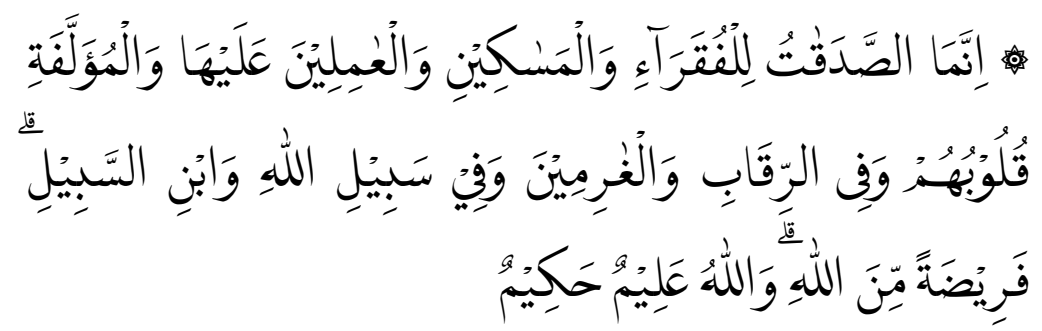

\begin{abstract}
Sesungguhnya zakat itu hanyalah untuk orang-orang fakir, orang-orang miskin, para amil zakat, orang-orang yang dilunakkan hatinya (mualaf), untuk (memerdekakan) para hamba sahaya, untuk (membebaskan) orang-orang yang berutang, untuk jalan Allah dan untuk orang-orang yang sedang dalam perjalanan (yang memerlukan pertolongan), sebagai kewajiban dari Allah. Allah Maha Mengetahui lagi Mahabijaksana (QS. At-taubah:60).
\end{abstract}

Ayat tersebut menjelaskan mengenai golongan yang berhak menerima zakat, isi dari surah At-Taubah ayat 60 dapat disimpulkan bahwa; (Fuadah, 2018)

1. Fakir dan miskin

Menurut Mazhaf Hanafi, fakir merupakan seseorang yang tidak memiliki kekayaan dan dibawah nilai nisab atau nilai sesuatu yang mencapai nisab terdiri dari perlengkapan rumah, baju, buku, dll. Sedangkan miskin yaitu seseorang tidak mempunyai harta apapun.

2. Amil zakat (pengelola zakat)

Pengurus zakat yaitu membantu mengumpulkan, menyimpan, mendistribusikan zakat.

3. Orang yang baru masuk Islam

Mualaf ialah keyakinan semakin meningkat terhadap Islam dan mereka akan menolong kaum muslimin dari musuh.

4. Riqab (kelompok yang memerdekakan budak)

Riqab merupakan kehidupan orang dikuasai sepenuhnya dikuasai oleh majikannya. Sehingga berhak untuk mendapatkan dana zakat agar mereka bisa melepaskan diri dari perbudakan.

5. Gharim (orang yang berhutang) 
Seseorang yang berhutang bukan dalam kemaksiatan ataupun menipu orang melainkan keadaan yang mendesak untuk memenuhi kebutuhan hidup sehari-hari.

6. Fisabilillah (berjuang dijalan Allah)

Fisabilillah ialah mereka berjuang agama Islam untuk mendapatkan ridha-Nya.

7. Orang dalam perjalanan

Ibnu sabil yaitu seseorang sedang berpergian dengan mengharapkan ridho Allah dengan bertujuan untuk kebaikan.

\section{Infak}

Kata infak berarti menyumbangkan harta yang diberikan Allah swt (Waton, 2017). Infak adalah ibadah sosial yang paling utama. Jadi, infak ialah membelanjakan harta di jalan Allah. Berdasarkan jenisnya, infak dibedakan menjadi dua jenis yaitu: (Fuadah, 2018)

1. Infak wajib

Merupakan dimulai bentuk nazar dan jumlahnya telah ditetapkan. Perjanjian untuk masa depan. Seseorang berjanji "jika saya diterima kerja kantor, saya akan memberikan Rp.300.000 kepada fakir miskin”. Karenanya harus memenuhi janji, jika tidak maka, akan dikenakan denda kifarat.

\section{Infak sunnah}

Infak sunnah adalah pemberian dilakukan oleh orang Islam untuk mendapatkan ridho-Nya dapat dilakukan dengan berbagai cara dan bentuk. Misalnya, memberikan makanan untuk korban bencana alam, dll. Orang yang berhak menerima infak antara lain:

1. Kerabat yaitu anggota keluarga yang harus diutamakan dengan memberikan nafkah ataupun dukungan kepada keluarga terdekat.

2. Anak yatim yaitu menyumbang kepada yatim piatu merupakan salah satu amalan yang dianjurkan oleh Allah dan Rasulullah. Disebabkan ditinggal orang tua kemudian, tidak berkecukupan untuk mewujudkan keinginan.

3. Orang miskin

4. Musafir yaitu mereka yang membutuhkan bantuan selama dalam perjalanan, dapat menghindari dari segala kesulitan. 


\section{Sedekah}

Sedekah artinya memberi sesuatu kepada orang lain. Sedekah berasal dari kata sadaqa jadi, sedekah adalah bentuk nyata ketakwaan seseorang melalui amal atau perbuatan positif terhadap sesama baik berupa barang ataupun jasa. Ketetapan sedekah sama halnya dengan infak mengenai materi sedangkan, sedekah mempunyai arti luas dalam pemberian yang sifatnya non materai seperti memberikan layanan, berbagi pengetahuan dan saling mendoakan. Beberapa syarat/ketentuan sedekah antara lain ; (Fuadah, 2018)

1. Memberikan persyaratan merupakan seseorang memiliki objek dan mempunyai hak membedakannya.

2. Orang yang diberi persyaratan memiliki hak artinya tidak sah memberikan kepada anak belum lahir atau memberi pada binatang, dari kedua tersebut tidak berhak untuk memiliki.

3. Ijab dan qabul. Ijab adalah pernyataan dari orang yang memberi sedangkan qabul adalah pernyataan penerimaan dari orang yang menerima pemberian.

Beberapa bentuk sedekah yaitu; (Fuadah, 2018)

1. Memberikan kepada orang lain berbentuk materi.

2. Berbuat kebaikan dan hindari kejahatan.

3. Berbuat adil bagi orang yang berselisih.

4. Membantu mengangkat barang milik orang lain ke dalam kendaraan.

5. Memberikan orang lain senyuman.

6. Menyingkirkan benda-benda tajam di tengah jalan yang dapat mengganggu perjalanan orang lain.

Infak, sedekah dan zakat diukur dari waktu pembayaran yaitu zakat fitrah waktu pembayarannya telah ditentukan sedangkan infak dan sedekah bisa kapan saja membayar sesuai kemampuan (Achmad, 2012).

\section{Konsep Pendistribusian}

Pendistribusian merupakan penyaluran/pengalokasian barang di sebagian tempat. Jadi penyaluran zakat diperuntukkan kepada yang berhak menerimanya baik secara produktif ataupun konsumtif. Hal ini diharapkan pemanfaatan dana ZIS secara optimal akan mencapai tujuan baik pendistribusian dan penyaluran (Marbun, 2019). Selanjutnya pendistribusian dibagi menjadi dua yaitu distribusi kekayaan dan distribusi pendapatan. Kekayaan yang dimiliki umat muslim merupakan titipan Allah swt, sehingga harta tersebut harus 
dimanfaatkan dengan baik (Agustini, 2017). Sedangkan distribusi pendapatan merupakan suatu instrumen penghasilan masyarakat seperti gaji (Almizan, 2016). Distribusi kekayaan dan pendapatan dalam Islam untuk meminimalkan kesenjangan ekonomi yang disebabkan oleh teori distribusi kapitalisasi yang memberikan kebebasan harta dan berusaha mendapatkan harta yang diperoleh individu maupun kelompok dengan cara yang tidak adil. Oleh karena itu, Islam memberikan batasan dalam memperoleh harta agar dapat memperhatikan keadilan yang dirasakan oleh masyarakat. Sehingga konsep distribusi dapat ditingkatkan agar kekayaan merata dan tidak menjadi milik ataupun golongan tertentu saja (Sariyati, 2020).

\section{Kesejahteraan}

Islam adalah agama yang rahmatan lil'alamin, tujuan utamanya dengan memberikan kebahagiaan bagi umatnya. Oleh karena itu, Islam sangat memperhatikan kebahagiaan dunia dan akhirat, diharapkan manusia bisa mendapatkan kesejahteraan, baik secara material dan spiritual (Fadlan, 2019).

Al-Ghazali dalam bukunya Ijtihad Maqasid di terjemahkan oleh Thahir (2015) Secara bahasa, maslahah merupakan manfa'ah baik dari bentuk (wazn) maupun maknanya. Dalam terminology usul alfiqh, maslahah dimaksudkan segala sesuatu dapat mewujudkan kebaikan serta terhindarnya segala macam madarrah (bahaya) atau mafsadah (kerusakan) dalam kehidupan manusia. Dengan demikian, ada atau tidaknya maslahah diukur dengan dua hal tersebut. Jika adanya kebaikan berarti maslahah. Sebaliknya, bila terjadi bahaya, ketimpangan, ketidakadilan dan sebagainya, berarti hal yang demikian itu disebut mafsadah (kerusakan) atau madarah (bahaya) (Thahir, 2015).

Menurut Al-Ghazali mencakup lima prinsip dasar: Agama (din), jiwa (nafs), akal (aql), keturunan (nasl) dan harta (mal). Segala sesuatu yang mencerminkan perlindungan terhadap lima prinsip tersebut disebut maslahah, sebaliknya setiap sesuatu yang dapat menyebabkan terabaikan ialah mafsadah (Thahir, 2015)

Kesejahteraan menurut Al-Ghazali dikutip oleh Widiastuti (2021) merupakan suatu kondisi dimana masyarakat dapat menjamin kebutuhan dasarnya seperti sandang, pangan dan papan (Widiastuti et al., 2021).

Menurut Al-Ghazali dalam mencapai kesejahteraan seseorang harus melakukan kegiatan ekonomi yaitu: pertama, memenuhi 
kebutuhan hidup. Kedua, mensejahterakan keluarga. Ketiga, menolong orang lain yang membutuhkan. Dari ketiga kriteria tersebut dapat disimpulkan bahwa tingkat kesejahteraan seseorang terpenuhi apabila kebutuhan mereka tercukupi. Tingkat kebutuhan dalam Islam terdiri dari:

1. Maqasid al-daruriyyat (tujuan primer) ialah tujuan yang wajib ada, sebab bila tidak ada akan berdampak menghancurkan kehidupan secara total (Thahir, 2015). Konsumtif tradisional berupa pangan dan sandang sehingga tidak lepas dari kedua kebutuhan itu. Kebutuhan pangan yaitu dengan memberikan makan dan minum tiga kali sehari yaitu pagi, siang dan malam. Diberikan tambahan gizi diantaranya vitamin, susu, protein, karbohidrat. Sedangkan konsumtif kreatif terdiri dari tempat tinggal, pendidikan, kesehatan dan rekreasi anak yatim (Hartanty, 2015).

2. Maqasid al-hajiyyat (tujuan sekunder) merupakan sesuatu yang diperlukan manusia untuk mempermudah pencapaian kategori daruriyyat. Karena itu, didukung dan dilengkapi tujuan primersekunder. Artinya, jika hajiyyat tidak ada, maka kehidupan manusia tidak akan hancur, tetapi akan terjadi berbagai ketidaksempurnaan, bahkan kesulitan (Thahir, 2015).

3. Maqasid al-tahsiniyyat (tujuan tersier) yaitu segala sesuatu yang kehadirannya tentu bukan dibutuhkan, tetapi bersifat akan memperindah. Proses perwujudan kepentingan daruriyyat dan hajiyyat. Sebaliknya, ketidakhadirannya tidak akan menghancurkan maupun mempersulit kehidupan, tetapi mengurangi keindahan dan etika (Thahir, 2015).

Jadi, dalam penelitian ini penulis menetapkan beberapa indikator sebagai bahan acuan untuk mengukur sejauh mana efektivitas dalam maqasid syariah oleh mustahik antara lain;

1. Memelihara agama (Hifzal-din)

Dharuriyat pada maqasid syariah adalah tercapainya kemaslahatan agama dan duniawi. Jika tidak ada maka, akan menyebabkan kerusakan atau ancaman kehilangan nyawa. Salah satu bentuk kebutuhan dharuriyat yang harus dilindungi ialah perlindungan agama. Indikator penelitian ini dilakukan oleh mustahik ditinjau dari aspek ibadah yaitu; taat dalam beribadah, kemudahan akses (sarana ibadah seperti mukena, sajadah, sarung) dan menunaikan kewajiban menuntut ilmu agama (Ferdaus, 2018). Pemeliharaan atas agama (hifz al-din) 
oleh para ulama maqasid sesudah Al-Ghazali, seperti alShatibiy, Alal al-Fasi dan Tahir bin 'Ashur dikaitkan dengan seluruh aspek ajaran agama Islam, mulai dari aspek aqidah (keyakinan), ibadah, mua'amalah dan lainnya. Selanjutnya seiring dengan perjalanan waktu, hifz al-din tidak hanya dipahami agama Islam, tetapi adanya kebebasan dalam beragama (Thahir, 2015).

2. Perlindungan jiwa (Hifz al-nafs)

Islam memperkenalkan konsep an-nafs al-muthmainnah artinya jiwa yang tenang. Tentunya, tidak mengabaikan tuntutan aspek material akan tetapi, memiliki keyakinan atas aktivitas dunia dengan keimanan. Sehingga, untuk mengukur indikator melalui kesehatan, artinya dapat memberikan jaminan kesehatan para mustahik dan kemudahan aksesbilitas/fasilitas kesehatan/pangan (Ferdaus, 2018). Perlindungan terhadap jiwa (hifz al-nafs), sebelum Al-Ghazali, mengungkapkan permasalahan yang lebih spesifik, yakni larangan membunuh (muzjirah qatl al-nafs), melindungi kehormatan (hifz al-'ird) dan larangan mengkhianati kehormatan (muzjirah thalb al- 'ird) (Thahir, 2015).

3. Perlindungan akal (Hifz al-aql)

Pemeliharaan akal melalui wawasan mustahik terhadap agama ataupun pengetahuan umum mengenai kewirausahaan, dengan memberikan pembinaan, pengawasan dan bimbingan (Ferdaus, 2018). Perlindungan terhadap akal (hifz al-aql) larangan minuman keras (al-khamr) dianggap dapat merusak akal pikiran. Kemudian jangkauan hifz al-aql diperluas oleh Qardhawi kewajiban dalam menuntut ilmu pengetahuan secara berkesinambungan hingga akhir hayat (min al-mahdi ila allahd), kewajiban merenung dan memikirkan jagat raya (malakut al-samawat wa al-ard) sehingga sesuatu yang berguna bagi dirinya dan umat manusia. Kemudian tokoh maqasid berikutnya, sayf'abd al-Fattah, mengembangkan konsep hifz alnasl kebebasan dalam berfikir (Thahir, 2015).

4. Perlindungan keturunan (Hifz al-nasl)

Keturunan merupakan anugerah sebagai amanah dari Allah swt. Keturunan yang baik harus sesuai dengan ajaran Islam dan menjauhi segala larangannya, seperti mengkonsumsi narkoba karena akan mengakibatkan buruk pada kesehatan sehingga, dapat terjadinya ancaman bagi keluarga dan keturunan. Oleh 
karena itu, indikator pengukuran melalui pendistribusian zakat terhadap pemeliharaan keluarga mustahik baik, secara rohani maupun jasmani (Ferdaus, 2018). Memelihara keturunan dalam pernikahan diutamakan pasangan yang berakhlak dan beragama, menutup aurat, untuk menjaga keturunan agar tidak rusak melalui penerapan hukuman zina dan tuduhan perzinaaan. Memelihara anak terkait bimbingan dan pendidikan kesehatan bagi setiap anak, adanya program kesehatan dan nutrisi anak, penanaman akidah berdasarkan sesuai Islam, memberian bekal keahlian bagi anak yang kurang mampu (Ratna, 2019).

5. Perlindungan terhadap harta (Hifz al-mal),

Menurut Monzer Kahf menyatakan bahwa, harta dalam pandangan Islam merupakan amanah dari Allah swt dan mencapai keberhasilan di hari akhirat. Harta yang diperoleh harus dengan cara halal, baik dan benar. Sedangkan menurut konvensional harta merupakan hak bagi setiap individu untuk mengukur pencapaian di dunia saja. Oleh karena itu, perlindungan harta ditinjau dari pendapatan sebelum dan sesudah menerima zakat oleh para mustahik (Ferdaus, 2018). Perlindungan terhadap harta (hifz al-mal) Al-'Amiri, sebelum Al-Ghazali, menyebutkan muzjirah akhdz al-mal (larangan mengambil harta) membahas tentang hukuman pencurian (alsariqab) dan perampokan (al-hirabah). Kemudian al-Juwaini mengubah 'ismah al-mal (perlindungan harta), dan disempurnakan oleh Al-Ghazali dengan konsep hifz al-mal prinsip diatas oleh Al-Ghazali dibedakan menjadi tiga peringkat, al-darurat, al-hajat dan al-tahsinat. Pengelompokan ini didasarkan pada tingkat kebutuhan dan skala prioritasnya (Thahir, 2015).

\section{METODE PENELITIAN}

Penelitian yang dilakukan dalam penelitian ini adalah penelitian kualitatif deskriptif dengan menggunakan pendekatan studi kasus. Selanjutnya lokasi pada penelitian ini dilakukan di Yayasan Indonesia Mulia, terletak di Blok M Sumber Jaya, Jl. Griya Asri 2 Blok E. 5 No. 29, Sumberjaya, Kec. Tambun Selatan, Bekasi, Jawa Barat 17510. 
Penelitian ini difokuskan pada mekanisme pendistribusian ZIS dan implikasi program pendistribusian terhadap kesejahteraan mustahik di Yayasan Indonesia Mulia Bekasi. Subjek penelitian ini adalah ketua pengurus Yayasan, sekretaris, bendahara dan para mustahik yang mendapatkan bantuan sosial khususnya anak yatim dan dhuafa. Dalam penelitian menggunakan sumber data primer dan sekunder. Selanjutnya teknik pengumpulan data menggunakan wawancara, observasi dan dokumentasi. Sehingga pada penelitian ini, peneliti memilih menggunakan triangulasi sumber data dan triangulasi metode. Teknik analisis data penelitian ini terdiri dari tahap pengumpulan data, reduksi data, penyajian data, penarikan kesimpulan dan verifikasi.

\section{HASIL DAN PEMBAHASAN}

\section{Mekanisme Pendistribusian Dana ZIS di Yayasan Indonesia Mulia Bekasi}

Program penyaluran yang dilakukan oleh Yayasan Indonesia Mulia Bekasi mencakup enam bidang yaitu program sosial, pendidikan, keagamaan, pembangunan, kemanusiaan dan kesehatan. Anak yatim dan dhuafa di Yayasan Indonesia Mulia berjumlah 93 orang yang terdiri dari laki-laki 46 orang dan perempuan 47 orang. Sehingga banyaknya anak yatim dan dhuafa yang terdaftar di yayasan pada lingkungan sekitar yayasan masih banyak yang kurang mampu. Anak binaan yang diasuh Yayasan memang tidak dibatasi namun bantuan untuk anak yatim hanya sampai lulus SMA/SMK saja. Persyaratan yang dibutuhkan anak yatim dan dhuafa sebagai penerima dana ZIS di Yayasan Indonesia Mulia. Bagi anak yatim, persyaratannya berupa surat kematian ayah/bapak, kartu keluarga, keterangan tidak mampu dari aparat setempat, diutamakan lingkungan sekitar yayasan dan batasan dan belum sekolah hingga SMA. Sedangkan untuk dhuafa persyaratannya yaitu keterangan tidak mampu, KTP, kartu Keluarga, janda/lansia dengan kategori tidak mampu dan kategori rumah kumuh atau sederhana. Beberapa program pendistribusian ZIS pada Yayasan Indonesia Mulia antara lain:

\section{Program Sosial}

Program sosial dilakukan dalam bentuk kegiatan santunan setiap bulannya untuk anak yatim dan dhuafa. Santunan rutin 
dilakukan pada peringatan hari besar Islam (PHBI). Selanjutnya ada santunan kunjungan dan undangan dari donatur. Santunan kunjungan artinya donatur yang berkunjung ke Yayasan Indonesia Mulia dan memberikan santunan kepada anak-anak yatim dan dhuafa secara langsung. Sedangkan untuk undangan dari donatur yaitu anak-anak yatim yang ke rumah donatur. Serta adanya kegiatan bakti sosial di lingkungan sekitar Yayasan. Bahkan sama halnya dengan Yayasan pada umumnya yaitu menerima dan menyalurkan zakat, infak dan sedekah.

Table 1. Rancangan Anggaran Biaya Santunan Untuk Anak

Yatim dan Dhuafa

\begin{tabular}{|c|c|c|c|c|}
\hline No. & $\begin{array}{l}\text { Uraian } \\
\text { Kebutuhan } \\
\text { Anggaran }\end{array}$ & Penerima & Anggaran & Jumlah \\
\hline 1 & $\begin{array}{l}\text { Anak Yatim } \\
\text { dan Piatu }\end{array}$ & 73 & $\begin{array}{l}\text { Rp. } \\
120.000\end{array}$ & Rp. 8.760 .000 \\
\hline 2 & $\begin{array}{l}\text { Kaum } \\
\text { Dhuafa/Jompo }\end{array}$ & 20 & $\begin{array}{l}\text { Rp. } \\
100.000\end{array}$ & Rp. 2.000 .000 \\
\hline
\end{tabular}

Rancangan Anggaran Santunan Perbulan $\quad$ Rp.10.760.000

Rancangan Anggaran Santunan Pertahun Rp.129.120.000

Sumber: Dokumentasi Yayasan Indonesia Mulia.

Tabel 2 menunjukkan bahwa penerima santunan yatim dan dhuafa ialah yang telah terdaftar di Yayasan Indonesia Mulia. Setiap anak yatim dan piatu diberikan sebesar Rp.120.000 sedangkan dhuafa/jompo santunan yang diberikan sebesar Rp.100.000. Sehingga dari seluruh rancangan anggaran santunan pertahunnya sebesar Rp.129.120.000. Hal tersebut disampaikan oleh Masrul (2021)

Penyaluran lebih ke konsumtif, usaha baru direncanakan, beberapa bulan lalu kita telah merencanakan untuk pemberdayaan, masih diprogram. Kalau untuk perbulannya dalam bentuk tunai Rp.100.000 (Masrul, 2021).

Santunan yang diberikan setiap bulannya untuk memenuhi kebutuhan, dan yang sering memberikan setiap bulannya yaitu 
civitas Yayasan khususnya divisi sosial dan bendahara Yayasan yang berkesempatan atau sudah menjadi panitia dalam acara tersebut. Selain itu, Yayasan menerima jumlah yang didapatkan dari donatur, yang setiap bulannya selalu berbeda-beda atau fluktuatif tidak menentu jumlahnya.

2. Program Pendidikan

Program pendidikan Yayasan Indonesia Mulia ialah kegiatan yang dilakukan untuk memberikan bimbingan belajar gratis kepada anak binaan yatim dan dhuafa, menumbuhkan minat baca dengan generasi bangsa, dapat mencerdaskan kehidupan bangsa dengan berbagai kegiatan edukatif, meningkatkan prestasi anak asuh baik akademik maupun non akademik, mengembangkan bakat, potensi dan keterampilan bagi anak-anak yatim dan dhuafa. Selain itu, pihak Yayasan juga memberikan perlengkapan sekolah seperti alat tulis, tas, sepatu. Nominal anggaran pendidikan secara keseluruhan sebesar Rp.5.000.000 untuk 20 anak diberikan masing-masing sebesar Rp.250.000. Sebagaimana yang di sampaikan oleh Maharani (2021)

Iya, dalam bentuk wifi, komputer, printer, alat tulis semacam buku, pulpen, penghapus, pensil, bahkan tas sekolah (Maharani, 2021).

3. Program Keagamaan

Program keagamaan diadakan dengan zikir, doa, pembacaan surat yasin dan istighosah, semua kegiatan dilaksanakan setiap malam jum'at serta adanya tahfidz AlQur'an yatim yang memiliki nilai hafalan lebih dan bacaan yang bagus untuk dibina. Lalu adanya wakaf Al-Qur'an untuk masjid yang diberikan kepada penghafal Al-Qur'an dan binaan yatim yang mengikuti tahfidz Al-Qur'an dan meningkatkan minat belajar Iqra dan Al-Qur'an bagi anak yatim dan warga sekitar Yayasan Indonesia Mulia. Nominal anggaran untuk program keagamaan sebesar Rp.6.000.000 sebanyak 60 orang anak dan masing-masing mendapatkan Rp.100.000. Kondisi ini sebagaimana disampaikan oleh Maharani (2021)

Pengajian sih rutin, istighosah, zikir terus apalagi kan sekarang bulan ramadhan kan sering bukber disini jadi sering melakukan tadarus 
bersama, shalat berjamaah, pokoknya kaya gitulah kak (Maharani, 2021).

4. Program Pembangunan

Saat ini Yayasan Indonesia Mulia sedang membangun program asrama yatim, kemudian juga membuka program pembangunan seperti wakaf tanah, sawah dan juga bangunan. Kini, program yang sedang berjalan adalah wakaf tanah yang telah diberikan oleh para donatur berupa wakaf bangunan yaitu rumah, selanjutnya memberikan renovasi fasilitas baik itu masjid ataupun musholah yang tertinggal dan juga sekolahsekolah yang mengalami rusak ataupun sekolah tertinggal dan pembebasan ruko untuk kegiatan belajar dan asrama. Maka dari itu program pembangunan memiliki nominal anggaran sebesar Rp. 2 milyar. Sebagaimana dipertegas oleh Alex (2021)

Pengumpulan dana donatur dari Yayasan ini kita alokasikan itu ke asrama yang hari ini kita bangun, untuk fasilitasnya anak yatim disitu semua. Yayasan Indonesia mulia masih ngontrak bukan hak milik. Jadi kedepannya karena sudah ada tanah wakaf, dibelakang Yayasan Indonesia mulia akan dibuat asrama anak yatim. Tujuannya anak-anak yatim piatu tinggal disana, sekaligus nanti kita bikin sekolah, aktifitas disitu.

\section{Program Kemanusiaan}

Program kemanusiaan ini dapat memberikan bantuan dengan sigap dan tanggap bencana alam diseluruh nusantara Indonesia, Yayasan Indonesia Mulia selalu membuka penggalangan untuk bencana alam yang ada di Indonesia tidak hanya dikhususkan pada lingkungan sekitar saja, seperti beberapa waktu yang lalu, adanya bencana banjir, gempa bumi, kebakaran, dan bencanabencana alam lainnya. Yayasan memberikan bantuan kepada masyarakat yang terkena bencana tersebut. Baik berupa nominal uang tunai ataupun barang layak dipakai dan makanan. Program ini memiliki tujuan untuk membantu masyarakat yang membutuhkan bantuan secara langsung dan cepat, khususnya dalam kondisi kesulitan. Sehingga program kemanusiaan dengan nominal anggaran sebesar Rp. 10.000.000/bulan.

6. Program Kesehatan

Yayasan Indonesia Mulia menyediakan program kesehatan dalam bentuk pengobatan gratis ataupun medical check up 
kepada binaan yatim, yatim piatu dan dhuafa. Namun, baru bisa dilaksanakan bilamana ada peringatan hari besar Islam (PHBI), meningkatkan kesehatan bagi binaan anak yatim, yatim piatu dan dhuafa serta masyarakat umum yang ada di sekitar lingkungan yayasan Indonesia mulia dan membantu meringankan beban kesehatan yatim dan dhuafa. Maka, program kesehatan dengan nominal anggaran secara keseluruhan sebesar Rp.10.000.000/bulan penerima sebanyak 93 orang. Sebagaimana disampaikan oleh Alex (2021)

Untuk layanan kesehatan medical check up itu kita adakan pertiga bulan jadi belum rutin setiap bulannya. Ketika ada anak yatim dan dhuafa memiliki penyakit kita adakan program untuk penyembuhan (Alex, 2021).

Selain itu, kegiatan yang dilakukan yayasan seperti adanya santunan bulanan, tadarus bersama, zikir bersama, istighosah, undangan dari donatur dan bimbingan belajar. Undangan dari donatur tidak diadakan setiap hari, hanya pada waktu tertentu saja dan tidak semua anak yatim bisa menghadiri undangan tersebut, dikarenakan anak asuh masih dalam berpendidikan formal sehingga tidak memungkinkan untuk mengikuti undangan. Undangan biasanya dilaksanakan pada hari libur yaitu sabtu dan minggu. Berbagai macam bentuk undangan seperti buka puasa bersama, santunan anak yatim dan lain-lain. Kegiatan buka puasa bersama tidak hanya anak yatim saja tetapi juga kaum dhuafa, tujuan diadakan buka bersama untuk menjalin silaturahmi. Santunan anak yatim di Yayasan Indonesia mulia yaitu untuk mencukupi segala kebutuhan baik itu sandang dan pangan. Sedangkan kebutuhan akan papan, Yayasan belum menyediakan tempat tinggal karena masih dalam proses renovasi pembangunan sehingga anak yatim atau yatim piatu bisa tinggal bersama keluarga ataupun saudara terdekat.

\section{Faktor Pendukung dan Penghambat Dalam Pendistribusian ZIS Yayasan Indonesia Mulia Bekasi}

Upaya yang dilakukan Yayasan Indonesia Mulia dalam meningkatkan kesejahteraan mustahik khususnya untuk anak yatim dan dhuafa yaitu dalam memenuhi kebutuhan hidup di bidang 
pendidikan seperti memberikan bimbingan pengetahuan agama ataupun umum, memfasilitasi dalam bentuk wifi, hp, laptop dan printer. Lalu ada santunan yatim dan dhuafa setiap bulannya, selain itu pemberian sembako yang berisi kebutuhan pokok dan juga perlengkapan sekolah. Sedangkan di bidang keagamaan kegiatan yang dilakukan seperti pembacaan surat yasin, zikir dan istighosah. Beberapa faktor yang mendukung pendistribusian yaitu:

1. Zakat memiliki peran penting dalam mengatasi kemiskinan.

2. Potensi zakat menjadikan sarana yang efektif untuk memberdayakan ekonomi umat. Jika potensi itu terus digali secara optimal dan dikelola dengan baik maka dapat membantu memandirikan anak yatim.

Selain itu, dukungan dari pengurus Yayasan yang tulus, ikhlas dan sabar dalam memberikan bimbingan, arahan dan pengawasan untuk anak yatim. Sehingga dukungan tersebut dapat memberikan hal positif bagi anak yatim.

Faktor penghambat setiap lembaga pasti mengalami hambatan seperti halnya dengan Yayasan Indonesia Mulia Bekasi yaitu sebelum adanya pandemi di setiap kegiatan santunan bersama anak yatim dan para donatur, anak yatim bisa semua hadir akan tetapi, hal itu tidak memungkinkan hanya sebagian saja serta harus menjaga jarak dan menjaga protokol kesehatan.

\section{Implikasi Pendistribusian ZIS terhadap Kesejahteraan Mustahik}

Secara umum, Yayasan Indonesia Mulia telah memenuhi peran pendistribusian dana ZIS dengan baik. Namun, salah satu indikator keberhasilan distribusi zakat yaitu tercapainya kesejahteraan para mustahik dengan maqashid syariah. Hal tersebut sebagaimana pendapat Chapra (2001) yang menyatakan bahwa jika maqashid syariah dijadikan sebagai tujuan dari perekonomian bangsa maka akan tercapai kesejahteraan perekonomian selanjutnya, penelitian Asmuni (2005) mengatakan bahwa maqashid syariah tidak hanya pemahaman teori linguistik Al-Qur'an tetapi memiliki peran sosial secara menyeluruh bagi kehidupan masyarakat terutama dari sisi moralitas (Ferdaus, 2018).

Maka dari itu pada penelitian ini, penulis menganalisis pendistribusian dalam meningkatkan kesejahteraan mustahik melalui 
maqashid syariah yang mencakup lima unsur yaitu perlindungan agama, jiwa, akal, keturunan dan harta.

1. Perlindungan Agama (Hifz al-din)

Menurut bahasa arab agama berarti ad-dien sedangkan secara istilah yaitu Allah swt menetapkan aturan-aturan yang ditujukan kepada manusia untuk mencapai kemaslahatan ummat. Perlindungan agama yang termasuk dalam kebutuhan dharuriyat sepenuhnya wajib dijaga. Jika agama rusak maka tatanan kehidupan juga rusak baik itu di dunia ataupun akhirat (Ferdaus, 2018). Perlindungan agama dilakukan salah satu dengan melaksanakan ibadah sesuai tuntutan syariah. Hal ini menjadi kebiasaan yang dilakukan oleh para yatim di Yayasan. Kegiatan ibadah yang dilakukan anak asuh di Yayasan antara lain:

a. Shalat berjamaah

Shalat berjamaah yaitu shalat yang dilakukan bersamasama, minimal sebanyak dua orang yang terdiri dari imam dan makmum. Hukum shalat berjamaah ialah sunnah muakad.

b. Pengajian bersama

Pengajian bersama yaitu kegiatan rutin yang berlangsung setiap malam jumat. Kegiatan pengajian tersebut biasanya diisi dengan berbagai kegiatan seperti membaca Al-Qur'an, shalawat dan zikir.

c. Istighosah

Istighosah termasuk berdoa dengan memohon pertolongan ketika mengalami kesulitan dan perlindungan. Kegiatan ini biasanya dilakukan bersama untuk mendoakan para donatur yang datang ke Yayasan agar diberikan keberkahan, kesehatan dan diberikan kemudahan rezeki.

d. Hafalan Al-Qur'an

Menghafal Al-Qur'an adalah kegiatan yang dilakukan untuk membaca dan memahami serta mengamalkan isi yang terkandung di dalam Al-Qur'an karena dengan membaca Al-Qur'an hati akan merasakan tenang.

Selanjutnya, kemudahan akses ibadah di Yayasan Indonesia Mulia terdiri dari ketersediaan mukena, sajadah, sarung, peci, Al-Qur'an dan anak yatim binaan di Yayasan Indonesia Mulia diwajibkan untuk menuntut ilmu agama sebaik 
mungkin, sehingga dapat memahami dan menerapkan dalam kehidupan sehari-hari terutama memiliki akhlak yang baik. Dalam penelitian ini, perlindungan agama mustahik diukur melalui beberapa indikator diantaranya: (Ferdaus, 2018)

a. Taat beribadah

Indikator yang digunakan untuk mencapai perlindungan agama yaitu memiliki komitmen dalam menjalankan agama oleh para mustahik melalui konsisten dalam menjalankan ibadah (Ferdaus, 2018). Ketaatan beribadah ditunjukkan oleh para yatim di Yayasan dengan melakukan shalat berjamaah dan membaca Al-Qur'an dan sudah diterapkan dalam kehidupan sehari-hari.

b. Kemudahan akses ibadah

Ibadah merupakan tiang agama, pada hakikatnya manusia diciptakan oleh Allah untuk beribadah. Maka dari itu, dalam memelihara agama mustahik dengan memberikan kemudahan akses ibadah yang menjadi salah satu indikator (Ferdaus, 2018). Berdasarkan penelitian yang dilakukan bahwa tempat ibadah belum memadai karena belum ada musholah ataupun masjid, adapun pelaksanaan shalat berjamaah dan kegiatan lainnya masih menggunakan aula. Namun, pihak Yayasan telah melakukan pemanfaatan dana ZIS untuk pembangunan tempat wudhu, mukena, sarung, sajadah, Al-Qur'an dan iqra. Hal-hal tersebut merupakan langkah yang dilakukan Yayasan guna memberikan akses pada para mustahik untuk beribadah.

c. Menuntut ilmu agama

Dalam Islam, menuntut ilmu merupakan ibadah dan kewajiban bagi setiap muslim (Ferdaus, 2018). Ilmu terbagi menjadi dua yaitu ilmu fardhu ain dan ilmu fardhu kifayah. Fardhu ain merupakan ilmu yang berkaitan dalam kehidupan sehari-hari yaitu ibadah seperti tata cara berwudhu, syahadat, shalat, puasa, zakat dan haji. Sedangkan ilmu fardhu kifayah yaitu ilmu yang berkaitan dengan pengetahuan umum misalnya ilmu ekonomi, politik, sosial, dll. Ilmu fardhu kifayah waktunya tidak ditentukan seperti shalat. Karena itu, pentingnya berilmu merupakan suatu kunci kesuksesan dalam beribadah. Bentuk penyaluran pada indikator ini Yayasan memberikan 
bantuan berupa biaya pendidikan anak yatim untuk melanjutkan pendidikan ke jenjang berikutnya dan berdasarkan hasil penelitian bahwa indikator pemahaman ilmu agama mustahik sudah dilakukan secara maksimal dan terpenuhi kebutuhannya.

2. Perlindungan Jiwa (Hifz al-nafs)

Unsur perlindungan jiwa diukur melalui indikator yaitu kemudahan akses kesehatan dan pangan. Perlindungan jiwa tidak hanya ketenangan pikiran tetapi juga tumbuh dari kesehatan. Kesehatan adalah hal terpenting yang harus dipenuhi dalam mencapai kesejahteraan suatu negara. Maka dari itu, upaya yang dilakukan pemerintah dalam mengentaskan kemiskinan dengan memberikan jaminan sosial (Ferdaus, 2018). Bentuk pendistribusian pada indikator ini yaitu pengobatan gratis dan medical check up. Namun fasilitas kesehatan ini belum sepenuhnya terpenuhi karena layanan kesehatan ini belum dilakukan secara rutin artinya untuk kesehatan masih perlu ditingkatkan. Sedangkan ketersediaan pangan tergantung dari cukup atau tidaknya pangan yang dikonsumsi.

Berdasarkan hasil penelitian ini ditemukan bahwa ketersediaan pangan mustahik terpenuhi, karena setiap bulannya Yayasan memberikan bantuan pangan dalam berbentuk kebutuhan pokok untuk memenuhi gizi baik dan hidup sehat. Yayasan Indonesia Mulia memberikan layanan kesehatan untuk yatim dan dhuafa yang sudah berlangsung setiap enam bulan sekali berupa check up dan diberikan vitamin, namun program kesehatan ini belum rutin. Kebutuhan akan biasanya setiap bulan atau setiap minggu dua kali atau tiga kali yang diberikan langsung oleh para donatur dalam bentuk beras, mie instan, telur, susu, gula dan minyak.

3. Perlindungan Akal (Hifz al-aql)

Dalam penelitian ini, pemeliharaan akal melalui wawasan mustahik terhadap agama atau pengetahuan umum mengenai kewirausahaan. Hal ini dapat ditinjau dari kondisi sebelum dan sesudah mendapatkan pembinaan, pengawasan dan pendampingan mustahik. Pada indikator pertama narasumber menyatakan bahwa mustahik Yayasan Indonesia Mulia telah mendapatkan pembinaan agama. Pembinaan keagamaan diadakan setiap seminggu sekali pertemuan yaitu hari kamis, 
dilaksanakan dari sore hari hingga malam hari, selebihnya anak yatim bisa hadir ke Yayasan setiap hari tanpa ada batasan untuk mendapatkan bimbingan belajar langsung mengenai pengetahuan umum.

Berdasarkan hasil penelitian bahwa pembinaan, pengawasan dan pendampingan melalui pengetahuan umum telah terpenuhi dan juga Yayasan Indonesia Mulia menyediakan fasilitas seperti wifi, komputer, printer, dan perlengkapan sekolah yang diberikan langsung oleh donatur untuk anak yatim dalam bentuk buku tulis, alat tulis dan lainnya. Sehingga pembelajaran agama pada Yayasan mengalami peningkatan, terutama pada saat bulan ramadhan. Yayasan memberikan arahan shalat yang baik dan benar, bimbingan belajar saat anak yatim mengalami kesulitan maka akan dibimbing langsung oleh pengurus Yayasan dan pengawasan setiap acara kegiatan santunan dari donatur kepada anak yatim dan dhuafa.

4. Perlindungan Keturunan (Hifz al-nasl)

Ferdaus dalam bukunya Auda (2013, p.53) menegaskan bahwa pada abad ke-20 M sesuatu yang dianggap penting almaqasid secara istilah ialah menjadi bagian keturunan dari sebuah teori maqasid yang mengarahkan pada keluarga. Hal tersebut selaras dengan dengan karya ibn Asyur berjudul Sistem Sosial Dalam Islam yakni dengan memperhatikan keluarga menjadikan salah satu tujuan pokok Islam. Segala sesuatu dapat memberikan nilai kesadaran dan keamanan terhadap keluarga. Seperti halnya dengan adanya ancaman terhadap kesehatan keluarga jika mengkonsumsi zat haram. Maka dari itu diukur melalui implikasi pendistribusian zakat terhadap pemeliharaan keluarga mustahik baik secara rohani dan jasmani. Pengukuran indikator melalui kemudahan akses pendidikan dan pemenuhan pangan (Ferdaus, 2018).

Pada indikator kemudahan akses pendidikan anak di Yayasan Indonesia Mulia sebagian besar anak asuh masih dalam usia sekolah (Ferdaus, 2018) Sehingga indikator ini cukup terpenuhi, baik dari segi fasilitas yang layak memadai dan juga para pembimbing yang dapat mengarahkan anak binaan mustahik menjadi orang sukses dan mandiri. Pada indikator kedua, pemenuhan pangan berkualitas dengan standard gizi yang baik, sehingga pemenuhan pangan cukup terpenuhi para mustahik (Ferdaus, 2018). Berdasarkan hasil 
penelitian ini bahwa Yayasan tidak memberikan biaya sampai menikah, hanya saja anak yatim dibiayai sampai tamat sekolah SMA, karena Yayasan memberikan bimbingan kepada anak yatim supaya kedepannya bisa mandiri. Bentuk penyaluran pendidikan diantaranya buku tulis, tas, sepatu ataupun alat tulis lainnya sedangkan pendistribusian pangan yaitu berbentuk makanan pokok.

5. Perlindungan Harta (Hifz al-mal)

Ferdaus dalam bukunya Auda (2013, p. 57) terkait pemeliharaan harta secara terminologi yaitu sosial ekonomi, dalam perkembangannya Al-Maqasid kontemporer artinya mengalami peningkatan keamanan sosial, mensejahterakan masyarakat, pembangunan ekonomi dan mengurangi kesenjangan antar kelas sosial. Maka dari itu, di dalam penelitian ini pemeliharaan harta, penulis ingin mengetahui pendapatan yang diperoleh sebelum dan sesudah menerima zakat oleh mustahik (Ferdaus, 2018). Bentuk penyaluran harta ialah aset kelolaan misalnya muzaki menentukan mustahik yang menerima zakat muqayyadah melalui amil tetapi tidak ada bagian amil atas zakat yang diterima. Namun, amil bisa memperoleh ujrah (fee) atas kegiatan penyaluran tersebut.

Berdasarkan hasil penelitian bahwa sebelum memberikan zakat kepada mustahik, Yayasan membuat agenda setiap bulan dalam bentuk proposal ataupun update melalui pesan WA, SMS, telepon dan media sosial lainnya. Mengenai jumlah kebutuhan zakat dan operasional yang akan diberikan kepada mustahik yang telah terdaftar di Yayasan. Kemudian jika sudah menerima zakat, Yayasan kembali fokus kepada pendidikan akhlak, keagamaan dan undangan-undangan kegiatan sosial lainnya dari donatur maupun agenda Yayasan. Jadi Yayasan ini hanya sekedar memberikan bantuan secara tunai/konsumtif yaitu perbulan rata-ratanya Rp.100.000, sedangkan untuk program produktif baru direncanakan.

Selain itu, pendistribusian zakat lebih mengutamakan prinsip keadilan, pemerataan dan kewilayahan. Artinya keadilan distribusi ini diberikan kepada orang yang berhak agar tepat sasaran dalam bentuk dana ZIS. Setelah memperhatikan keadilan maka akan terjadinya pemerataan untuk mensejahterakan ekonomi para mustahik dalam bentuk bantuan 
sosial serta kondisi ekonomi pada wilayah tertentu, yang berkaitan dengan pengalokasian dana zakat diutamakan pada lingkungan sekitar Yayasan karena masih banyak anak yatim dan dhuafa yang membutuhkan bantuan seperti pendidikan, pangan, kesehatan.

Saat ini Yayasan Indonesia Mulia sedang membangun asrama yatim. Bentuk penyaluran bantuan ini dengan memfasilitasi dan membimbing anak yatim, agar kedepannya anak yatim bisa tercukupi segala kebutuhannya. Sehingga Yayasan ini memiliki peningkatan dari tahun ke tahun yakni dengan adanya program pembangunan untuk asrama yatim yang terus dikembangkan agar bisa menjadikan aktivitas kegiatan belajar dan tempat tinggal.

\section{KESIMPULAN}

Berdasarkan hasil penelitian, penulis menyimpulkan bahwa pendistribusian dana ZIS di Yayasan Indonesia Mulia bekasi, memiliki beberapa program yang telah dilaksanakan. Program pertama adalah program sosial yang bentuk kegiatannya berupa santunan rutin anak yatim. Program kedua adalah program pendidikan yaitu kegiatan yang dilakukan dengan memberikan bimbingan belajar gratis kepada anak asuh dan memberikan kebutuhan perlengkapan sekolah. Program ketiga adalah program keagamaan yang dilakukan dengan zikir, berdoa, pembacaan surat yasin dan istighosah kegiatan rutin yang dilakukan setiap malam jumat. Program keeempat merupakan program pembangunan berupa wakaf bangunan yang akan dijadikan asrama yatim. Program kelima adalah program kemanusiaan yaitu memberikan bantuan kepada masyarakat yang terkena bencana alam. Program keenam merupakan program Kesehatan dalam bentuk pengobatan gratis ataupun medical check up. Indikator keberhasilan pada pendistribusian ZIS yaitu tercapainya kesejahteraan para mustahik yang diukur dengan indikator maqashid syariah diantaranya: pemeliharaan agama, akal, keturunan, jiwa dan harta. Pertama hifz al-din, diimplementasikan dengan shalat berjamaah, pengajian bersama, istighosah dan hafalan Al-Qur'an. Kedua hifz nafs, diimplementasikan dengan indikator kemudahan 
akses kesehatan dan pangan. Ketiga hifz aql, diimplementasikan dengan pemeliharaan akal melalui wawasan mustahik terhadap agama ataupun pengetahuan umum mengenai kewirausahaan, dengan memberikan pembinaan, pengawasan dan bimbingan. Keempat hifz nasl, diimplementasikan dengan pemeliharaan keturunan diukur melalui pemenuhan rohani dan jasmani selain itu, dengan memberikan kemudahan akses pendidikan dan pangan. Kelima hifz mal, diimplementasikan dengan pendapatan sebelum dan sesudah menerima zakat, sehingga indikator ini belum terpenuhi karena bantuan ini bersifat sementara/konsumtif. Berdasarkan indikator maqasid syariah, bahwa program penyaluran zakat pada Yayasan Indonesia Mulia Bekasi memiliki dampak yang signifikan dalam meningkatkan kesejahteraan mustahik.

\section{REFERENSI}

Achmad, Y. (2012). Inilah Perbedaan Zakat, Infak dan Sedekah Yang Wajib Anda Pahami. 29 Juni. Inilah Perbedaan Zakat, Infak dan Sedekah Yang Wajib Anda Pahami

Afni, N. (2020). MANAJEMEN DAN PENDISTRIBUSIAN ZAKAT DALAM UPAYA PENINGKATAN KESEJAHTERAAN SOSIAL MASYARAKAT. Jurnal Studi Ilmu Pengetahuan Sosial, 1(2).

http://moderasi.org/index.php/moderasi/article/view/30/23

Agustini, A. W. (2017). DISTRIBUSI KEKAYAAN DALAM EKONOMI SYARIAH. Jurnal Keislaman, Kemasyarakatan \& Kebudayaan, 18(2). file:///C:/Users/hp/Downloads/document (2).pdf

Almizan. (2016). Distribusi Pendapatan: Kesejahteraan Menurut Konsep Ekonomi Islam. Jurnal Kajian Ekonomi Islam, 1(1). file:///C:/Users/hp/Downloads/16-50-2-PB.pdf 
Ansori, T. (2018). PENGELOLAAN DANA ZAKAT PRODUKTIF UNTUK PEMBERDAYAAN MUSTAHIK PADA LAZISNU PONOROGO. Muslim Heritage, 3(1).

file://C:/Users/hp/Downloads/1274-3316-1-PB.pdf

Baznas, H. (2020). BAZNAS : Zakat Masyarakat yang Tak Tercatat Rp 61,25 Triliun. Www.Baznas.Go.Id.

https://baznas.go.id/Press_Release/baca/BAZNAS_:ZZakat_Mas yarakat_yang_Tak_Tercatat_Rp_61,25_Triliun/680

Fadlan. (2019). Konsep Kesejahteraan dalam Ekonomi Islam: Perspektif Maqashid al-Syariah. Jurnal Ekonomi Syariah. file:///C:/Users/hp/Downloads/916-3330-1-PB.pdf

Ferdaus, N. N. (2018). PENCAPAIAN NILAI MAQAŞID SYARIAH OLEH MUSTAHIK ZAKAT PRODUKTIF : STUDI KOMPARATIF LAZIS YBW UII \& BAZNAS KOTA YOGYAKARTA.

file://C:/Users/hp/Downloads/SKRIPSI_FIX.pdf

Fuadah, I. N. (2018). Pendayagunaan Dana Zakat, Infaq, Shadaqah dan Wakaf (ZISWAF) untuk Pemberdayaan Ekonomi di Baitul Maal KSPPS Binama KC Tlogosari.

http://eprints.walisongo.ac.id/9031/1/TA LENGKAP.pdf

Hafidhuddin, D. (2002). Zakat dalam perekonomian modern. Gema Insani

Hartanty, D. (2015). Manfaat Bantuan Konsumtif Kreatif Terhadap Anak Yatim Tinjauan Ekonomi Islam. Jurnal Hukum Islam, 15(2). file:///C:/Users/hp/Downloads/2076-6884-1-PB.pdf

Hudayati, A., \& Tohirin, A. (2019). A Maqasid and Shariah

Enterprises Theory-BasedPerformance Measurementfor Zakat Institution. International Journal of Zakat, 4(2).

https://www.ijazbaznas.com/index.php/journal/article/view/192/ 77

Kamalia, M. H., Ali Akbar, M. A., Enny Nazrah Pulungan, M. A., \& Nurliana Damanik, M. A. (2018). Kiprah Yayasan Ash-Shilah Dalam Peningkatan Mutu Pendidikan, Ekonomi dan Status Sosial Anak Yatim di Kota Medan. 
file://C:/Users/hp/Downloads/Kamalia dkk Kiprah Yayasan Ash-Shilah Dalam Peningkatan anak yatim.pdf

Marbun, R. (2019). ANALISIS PENDISTRIBUSIAN, PENDAYAGUNAAN ZAKAT, INFAQ, SHADAQAH PADA MUSTAHIQ STUDI KASUS LAZISMU KOTA MEDAN. file:///C:/Users/hp/Downloads/Analisis Pendistribusian, Pendayagunaan Zakat, Infaq, Shadaqah Pada Mustahiq (Studi Kasus Pada Lazismu Kota Medan).pdf

Mardani. (2012). Fiqh ekonomi syariah : fiqh muamalah. Kencana Prenada Media.

https://www.google.co.id/books/edition/Fiqh_Ekonomi_Syariah/ ncDvDwAAQBAJ?hl=id\&gbpv=1

Nur, H. R. (2018). Efektivitas Pendayagunaan Dana Zakat, Infaq, Shadaqah Perspektif Maqashid Syariah. file:///C:/Users/hp/Downloads/NASKAH PUBLIKASI_14423210.pdf

Nurhasanah, S., \& Suryani, S. (2018). MAKSIMALISASI POTENSI ZAKAT MELALUI PENINGKATAN KESADARAN MASYARAKAT. JEBI (Jurnal Ekonomi Dan Bisnis Islam), 3(2), 185-194. file:///C:/Users/hp/Downloads/177-547-2-PB.pdf

Ratna. (2019). Analisis Sistem Distribusi Dana Zakat, Infak, dan Sedekah (ZIS)) Pada Dompet Dhuafa Cabang Sumsel Berdasarkan Tingkat Maqashid Syariah. Jurnal Stitqi.Ac.Id, 1(1). file:///C:/Users/hp/Downloads/279-552-1-SM.pdf

Riskyana, D. (2019). EFEKTIVITAS PENDAYAGUNAAN DANA ZAKAT INFAK SEDEKAH DAN WAKAF (ZISWAF) MELALUI PROGRAM MANDIRI ENTREPRENEUR CENTER (MEC) YATIM MANDIRI SURABAYA. http://digilib.uinsby.ac.id/35903/1/Devy Riskyana_C07215001.pdf

Robimadin, C. N. (2020). KEBERMANFAATAN ZAKAT PRODUKTIF UNTUK PENINGKATAN KESEJAHTERAAN MUSTAHIQ LEMBAGA MANAJEMEN INFAQ

SURABAYA. Jurnal Ekonomika Dan Bisnis Islam, 3(2). file:///C:/Users/hp/Downloads/34570-42875-1-PB.pdf 
Sariyati, B. (2020). ANALISIS DISTRIBUSI ZAKAT, INFAK DAN SEDEKAH DALAM PENANGGULANGAN PANDEMI COVID19 PERSPEKTIF MAQASHID SYARIAH (Studi Kasus BAZNAS Republik Indonesia). http://erepository.perpus.iainsalatiga.ac.id/9735/1/TESIS BIDAH SARIYATI.pdf

Syahadah, W. (2017). Analisis Tingkat Efisiensi Organisasi Pengelola Zakat (OPZ) Di Indonesia Dengan Menggunakan Data Envelopment Analysis (DEA) Periode 2013-2015. http://eprints.ums.ac.id/53422/11/PUBLIKASI ILMIAH.pdf

Thahir, A. H. (2015). Ijtihad Maqasidi; Rekonstruksi Hukum Islam Berbasis Interkoneksitas Maslahah. LKIS Pelangi Aksara. https://play.google.com/books/reader?id=F89iDwAAQBAJ\&hl= id\&pg=GBS.PA36

Wahyuningsih, R. (2018). ANALISIS FAKTOR-FAKTOR YANG BERPENGARUH TERHADAP KEBERHASILAN PENDAYAGUNAAN ZAKAT DALAM MENINGKATKAN KESEJAHTERAN MUSTAHIK DENGAN METODE STRUCTURAL EQUATION MODELLING PARTIAL LEAST SQUARE. file:///C:/Users/hp/Downloads/14611079_RINA WAHYU.pdf

Waton, S. (2017). EFEKTIVITAS PENDAYAGUNAAN DANA (ZIS) ZAKAT, INFAK DAN SEDEKAH DALAM PENINGKATAN KESEJAHTERAAN MUSTAHIK DI KECAMATAN PULOGADUNG JAKARTA TIMUR.

file://C:/Users/hp/Downloads/SALIM WATON-FEB.pdf

Widiastuti, T., Auwalin, I., Rani, L. N., Mawardi, I., Al Mustofa, M. U., Rosyidah, N., \& Mahmudah, S. N. (2021). Does Zakat and Non-Zakat Empowerment Affect Mustahiq Welfare Based on Maqashid Shariah? Journal of Islamic Economics, 5(1), 76-96. file:///C:/Users/hp/Downloads/10515-36495-2-PB.pdf 